\title{
Er islam ufredens religion?
}

\author{
Nøgleord \\ islamdebat; vold; jihadisme; \\ fortolkning; Martin Krasnik; \\ orientalisme
}

1. Genoptrykt efter aftale med

Martin Krasnik og Weekendavisen.

\begin{abstract}
Den 10. juni 2017 skrev Martin Krasnik en leder i Weekendavisen under overskriften "Ufredens religion", som Jakob Skovgaard-Petersen skrev et modsvar til på Facebook den 15. juni 2017. Hen over sommer fulgte en længere debat på Facebook og i flere dagblade om forholdet mellem islam og vold. Vi genoptrykker her den del af debatten, som udfoldede sig mellem Jakob Skovgaard-Petersen og Thomas Hoffmann på Facebook, suppleret med et nyt indlæg fra dem hver. Det er ikke kun en debat om, hvorvidt islam er fredens eller ufredens religion, men $\mathrm{i}$ lige så høj grad en debat om, hvordan både forskere og journalister bør gå til de islamiske tekster og muslimers fortolkninger heraf, både historisk og i dag.
\end{abstract}

\section{Martin Krasnik: “Ufredens religion”, ledende artikel i Weekendavisen, 10. juni 2017'}

Mindre end to uger efter terrorangrebet på børn og unge mennesker i Manchester skete det igen: Tre muslimer dræbte og lemlæstede tilfældige mennesker i London. Hvis der ikke har været nye angreb efter denne avis-deadline torsdag eftermiddag, har der i år hidtil været ni terrorangreb udført af muslimer i Vesteuropa. Sidste år var tallet 24. Læg dertil angrebene i Tyrkiet og Rusland, som får listen over ofre for religiøs terror til at vokse markant. Tilføjer man religiøst motiverede angreb på civile i Mellemøsten, bliver optællingen helt uoverskuelig. Lad os blot nævne disse uhyrligheder: I denne uge slog jiha-

Jakob Skovgaard-Petersen er professor i islam i den arabiske verden på Københavns Universitet, Institut for Tværkulturelle og Regionale Studier. Han er magister i religionshistorie fra KU og læste videre i Leiden. Blev dr.phil. på afhandlingen Defining Islam for the Egyptian State (1997). Han har boet, studeret og forsket i Cairo, Damaskus og Beirut og var 2005-08 direktør for det DanskEgyptiske Dialoginstitut.

Thomas Hoffmann er professor (mso) i Koran- og Islamstudier, Teologisk Fakultet, Københavns Universitet. Han er uddannet i religionshistorie ved Københavns Universitet og blev ph.d. fra Litteraturvidenskab på afhandlingen The Poetic Qurän. Studies on Qur'ānic Poeticity (2007).

Tidsskrift for Islamforskning $12(1) \cdot 2018 \cdot 106-133$ 
dister, muligvis fra Islamisk Stat, 12 mennesker ihjel i Iran. I Kabul i sidste uge blev 150 dræbt af en bilbombe, de fleste civile, deriblandt mange børn. Dertil kommer hyppige angreb på den koptiske minoritet i Egypten og massakrer på civile oftest shiamuslimer i Irak. I Pakistan forfølges og angribes kvinder, kristne, frafaldne, homoseksuelle og andre minoriteter for at bryde islamiske regler og love. I Saudi-Arabien gennemsyrer det hele samfundet. I afrikanske lande angribes civile af islamistiske grupperinger. Og i fjernere dele af den muslimske verden føres religiøs krig med velkendte mål og midler.

Religion er et emne, vi har svært ved at diskutere. Sund fornuft og dømmekraft kortsluttes, forstand fortrænges af ønsketænkning. For eksempel har der i årenes løb bredt sig den mærkværdige opfattelse, at islam er "fredens religion". Sådan har det lydt fra alskens vestlige politikere, fra religiøse muslimske ledere og ikke mindst fra de mange millioner og atter millioner muslimer, der blot vil leve i ro og fred med deres religion. Jo oftere uskyldige civile dræbes med henvisning til islam, islamiske dogmer og islamiske tekster, desto mere afvises det, at religionen har noget med sagen at gøre.

Er islam virkelig fredens religion, må der være noget, det meste af den muslimske verden har misforstået. Her råder nemlig ufred overalt. De fleste muslimsk dominerede stater holdes i et religiøst jerngreb, hærges af religiøs vold, social tvang og ufrihed; elendigheder, der også præger store dele af det muslimske mindretal i Europa. Der bruges uanede mængder af energi på at finde forklaringer: social armod, kriminalitet, kolonitidens arv, vestlig udenrigspolitik. Men der bruges meget lidt tid på at finde svaret der, hvor volden selv henter sin legitimitet.

Godt vil det derfor være at tale klart: Terroristerne har ikke svært ved at retfærdiggøre deres handlinger med islam. Ofte bortforklares det med, at alle religioner da har potentiale for ekstreme fortolkninger. Og ja, der er ingen tvivl om, at de tre monoteistiske religioner alle leverer rigeligt gods til voldsparate mennesker. Påstanden om at indehave en ufejlbarlig tekst og besidde en universel sandhed, der ekskluderer alle andre end de rettroende, er i sig selv uegnet til fredelig sameksistens. Kristendommen har ufattelige lidelser på samvittigheden: Med kravet om at udbrede den sande lære til alverden fulgte ofte slaveri, undertvingelse og etniske udrensninger. At sætte spørgs- 
målstegn ved det kristne monopol på magt, viden og moral blev straffet med døden. Den romersk-katolske kirke er skyld i ufattelige lidelser, ligesom de protestantiske aflægninger har stor elendighed på samvittigheden. Jødedommen, der som islam er en lovreligion, har det uhyggeligt svært med minoriteter og anderledestænkende, og i Israel undergraver religiøse grupper konsekvent demokrati og retsstat. Når religiøse jøder får politisk magt, følger ikke fred og kompromis, tværtimod. Det samme kan man sige om islam, hér er det blot endnu værre. Der er ikke et eneste muslimsk land, man ville have lyst til at bo i, hvis man ønsker at leve frit endsige udfolde sin kritiske sans offentligt.

Mindre ønsketænkning er nødvendig. Det vil være en hård opgave at forvandle islam til en fredens religion. Islam påstår at have svar på alle livets spørgsmål og hele samfundets indretning. Islam mener ikke blot at indehave sandheden, men den endelige åbenbaring og det endda givet i en ufejlbarlig tekst til et ufejlbarligt menneske. Angreb på dogmerne er et angreb på denne totalitære, endegyldige sandhed. Det fører ikke til fredelig sameksistens. At undertrykkelse af kvinder, vantro og frafaldne er en del af denne ufravigelige sandhed fører ikke til fredelig sameksistens. Forherligelse af krig, undertvingelse af fjender og den absolutte tro på, at verden går under med én sand sejrherre stående tilbage, det fører heller ikke til fredelig sameksistens.

Islam er mere ufredelig end de to andre monoteistiske religioner. Det forklarer ikke alene, hvorfor markant færre jøder og kristne går og myrder deres medborgere i religionens navn eller henholder sig til de samme dogmer som voldsmænd. Det skyldes, lyder det ofte, at jødedom og kristendom har gennemlevet hver sin reformation, så der i dag findes stærkt troende reformerte og konservative jøder og kristne, der for længst er holdt op med at tage deres religions dogmer og tekster bogstaveligt. Det afgørende er dog, at den vestlige verden har udsat sig selv for flere hundrede års sekularisering og oplysning, hvor det religiøse monopol på moralsk, kulturel og politisk magt ét for ét er faldet. Denne sekularisering har været helt fraværende eller meget overfladisk i den muslimske verden.

Er islam ikke en fredelig religion, må man stille spørgsmålet: Kan den blive det? Måske hvis muslimer helt grundlæggende forandrer deres religion. Den såkaldt ekstreme udgave af 
islam er desværre en ganske plausibel fortolkning af teksterne, og er man religiøs muslim, er det nærmest umuligt at finde institutionaliserede, dominerende udgaver af islam, der klart lægger afstand til de dele, der er uforenelige med demokrati, frihed og ligestilling. Der findes stort set ingen religiøse ledere med vægt og anseelse, der åbent siger det nødvendige: at muslimer ikke er forpligtet på de religiøse love, ikke skal drømme om et religiøst samfund, ikke er overordnet andre religioner, og at islams påstand om tekstens og profetens totale ufejlbarlighed og deraf følgende fortrængning af fri tænkning er dybt skadelig og må forandres.

Bedst vil det naturligvis være, hvis forandringen kunne ske i god ro og orden. Hvis terrorister og voldsmænd virkelig er forkerte muslimer, må alle de rigtige muslimer jo tage ansvaret for at lade deres religion gennemstråle af oplysning og sekularisering. Problemet er blot, at det har lange udsigter, og hvis denne proces allerede er i gang, må man sige: Det bliver en lang og blodig affære, en historisk værdikamp mellem sekulær frihed og religiøs totalitarisme. Her skal de vestlige samfund forsvare sig. Myndighederne skal konfrontere og bekæmpe kravet om eksklusivitet fra statens love og samfundets normer. Staten skal gå langt for at kontrollere og overvåge de kræfter, der er parate til at dræbe civile på enhver given dag overalt i Europa. Politikerne skal naturligvis også tage det dybt seriøst, at så mange europæiske muslimer finder en stærkere identitet i islam og bekæmpe de årsager, der kan findes til det. Tilbage står, at der stadig vil være mange muslimer, unge og gamle, mange af dem født i Europa, som bekender sig til en religion, som ikke bare står i modsætning til de samfund, vi ønsker, men danner en ring omkring dem af deres trosfæller, der er parate til at slå børn i Manchester og unge i London ihjel for at udbrede den sande tro. Mange insisterer på, at vi derfor, i det sekulære, gudløse Europa, selv skal finde tilbage til religiøse værdier og tankesæt for at kunne bekæmpe det. Det vil være helt forkert. Det, der har gjort vores samfund frie, åbne og demokratiske, er ikke religion, men oplysningens krav om at sætte mennesket frit. Frit til at tænke, tale og leve. Heri ligger nogle meget hårde principper, der skal håndhæves dagligt. Det er dét, vi skal insistere på over for alle, der lever i vores del af verden. 


\section{Jakob Skovgaard-Petersen:"Er islam ufredens religion?", postet på Facebook, 15. juni 2017}

Martin Krasnik har skrevet en leder i Weekendavisen om "ufredens religion", hvormed han mener islam. Der står mange fornuftige ting; han slår fast, at alle religioner har en voldshistorie og et voldspotentiale, men at det i dag er islamisk vold, der er truslen, også imod muslimer. Og at det er afgørende vigtigt at nedkæmpe og imødegå voldelige islamiske ideologier og bevægelser, ligesom det er komplet uacceptabelt, at der i Europa er muslimer, der sympatiserer med deres terror imod civile.

Alligevel er jeg uenig i Krasniks overordnede argumentation, som altså går på, at islam som sådan er ufredens religion. At mene andet, siger han, er "ønsketænkning” og udtryk for, at "sund fornuft og dømmekraft kortsluttes", når vi diskuterer religion. Krasnik opponerer imod, at muslimske ledere og andre muslimer kalder islam for "fredens religion" - nu der begås så mange voldelige uhyrligheder i islams navn: "Jo oftere uskyldige civile dræbes med henvisning til islam, islamiske dogmer og islamiske tekster, desto mere afvises det, at religionen har noget med sagen at gøre."

Det er i mine øjne netop, hvad disse millioner af muslimer og deres ledere skal gøre. Det er en islamisk formulering af den afstandtagen, vi så gerne ser. Og det er et led i en intern kamp mellem muslimer om at repræsentere sand islam. Det er ikke, fordi disse fredselskende muslimer nægter at se den virkelighed i øjnene, at terroristerne påberåber sig islam - det ved de udmærket godt finder sted. Det er, fordi de nægter at lade terroristernes islam være deres. Det er ikke virkelighedsfornægtelse, men terrorfordømmelse. Det er i virkeligheden også sådan, Obama brugte det; igen var han jo helt klar over truslen fra jihadisterne og beordrede selv droneangreb, mord på ledende jihadister osv. Så selvfølgelig var der ikke tale om, at Obama var naiv, men om, at han kom med et vigtigt politisk udsagn, henvendt til muslimer i USA og andre steder, om, at han ikke tog jihadisternes version af islam som den rigtige.

Vi andre - forskere og redaktører, f.eks. - skal derimod ikke sige, det er den forkerte heller. Det er ikke vores opgave at fastslå, at islam er fredelig eller voldelig, men vi skal konstatere, at sådanne modsatrettede tolkninger af islam hver har deres fortalere blandt muslimer, og hver med deres argumenter, fra 
skriften, historien og andre steder. Vi må erkende og agere på, at jihadister (terrorister med en specifik islamisk begrundelse for deres vold) findes og truer os. Vi må undersøge deres handlinger, rekruttering og ideologi, og hvordan de kan imødegås - herunder muslimske argumenter og strategier. Men vi skal naturligvis ikke kanonisere jihadisternes udlægning af islam som den rigtige.

Det er bare det, Krasnik kommer til, når man omvendt de-legitimerer de muslimer, der afviser, at det har noget med islam at gøre. Han forklarer i virkeligheden, at jihadisterne følger det, der står i de muslimske autoritative skrifter, mens deres modstandere ikke gør det, eller gør det mindre. Jihadisterne er de rene og konsekvente muslimer. For Krasnik ved, hvad "islam påstår”, og hvad “islam mener”. Han har åbenbart interviewet islam.

Jeg er med på, at særligt muslimske ledere gerne må gå i offensiven og detaljeret og konkret forklare, hvor og hvordan jihadisterne fortolker islam forkert. Det sker også. Men der måtte gerne være mere af det. Jeg er også med på, at mange ting er grundigt galt i den muslimske verden. Men at skyde skylden på islam for alle disse dårligdomme er forfejlet. I det meste af nyere tid har krig og ufred drejet sig om andre ting end religion: kolonialisme, Israel, kold krig, nationalistiske og socialistiske ideologier. Islam var som sådan ikke en central faktor. Selv om der er forløbere, er jihadismen som fuldt udviklet ideologi et produkt af afkoloniseringen, og egentligt jihadistiske grupper træder først frem på scenen i 1970'erne. I det 20. århundrede opstår der også andre, i perioder ret toneangivende, tolkninger af islam, herunder at den er "fredens religion". Den sekulariserede "westfalske" ide om, at verden består af stater, som kan have en religiøs identitet, men alligevel leve med hinanden i fred, er faktisk også blevet normen i den muslimske verden og fremmet af muslimske lærde, selv om man mente noget andet i middelalderen.

Disse krigeriske og fredelige tolkninger er historiske og vil blive forandret. De er kort sagt ikke noget, "islam påstår", men noget, som nogle lærde, magtfulde eller jævne muslimer påstår, at islam påstår. For os, der har studeret de her ting i årtier, er det udviklingerne i muslimernes trosopfattelser og verdenssyn, der er så slående. Ligesom i øvrigt i andre religioner. Igennem det seneste hundrede år har muslimer i Muhammad set en krigsherre og en fredsfyrste, en kapitalist og en socialist. 
Det er i den forbindelse vigtigt også at gøre op med Krasniks opfattelse af sekularisering som noget uafvendeligt og godt, samt at den muslimske verden lever i en slags præ-oplysningstid. Det er ikke tilfældet. Den lever i vores samtid. Og ligesom i jødedommen og kristendommen har der været og er fremdeles væsentlige nytolkninger af islam, ofte inspireret af normer og værdier, som muslimer deler med deres ikke-muslimske samtid. På godt og ondt. For det går ikke nødvendigvis mod det bedre.

Krasnik synes at mene, at nogle religioner for altid er kommet home free takket være "sekularisering og oplysning". Men mange af de mest barbariske udviklinger i religionerne har fundet sted som en respons på sekularisering og oplysning, ikke før. De største massakrer i menneskehedens historie fandt sted i det 20. århundrede, og det var kun i mindre omfang muslimer, og i større omfang katolikker, protestanter, ateister og andre, der begik dem. En ædruelig sammenligning af Vestens og den islamiske verdens historie vil ikke simpelthen vise "fredens religion" i vest og "ufredens religion" i øst.

Så rimelig Krasnik umiddelbart kan lyde, rummer hans tekst derfor ingen løsninger, men røber i stedet nogle af problemerne ved det dominerende tankesæt i den danske debat: nemlig at islam er et "altomfattende system" som "både er stat og religion", nedfældet i deres grundskrift, som determinerer muslimernes handlinger. Og at ingen muslim - læg eller lærd har turdet gøre op med dette system.

Endelig er det en skam, at en så fornuftig og redelig mand som Martin Krasnik indirekte siger, at det at benægte, at islam som sådan er ufredens religion, er lig med "ønsketænkning" og kortsluttet dømmekraft. Hvorfor er det så vigtigt for ham, at vi ikke skal koncentrere os om de muslimer, der vitterligt er krigeriske og voldelige (og andre som er sexistiske, chauvinistiske og bigotte), men derimod "islam" selv - et islam, som "mener" og "påstår” noget ganske specifikt?

Og hvorfor skal vi, der ikke er enige - millioner af muslimer og næsten alle seriøse ikke-muslimske forskere - fratages fornuft og dømmekraft? Det lyder som nogle af de evige islamdebattører, der skjuler, hvor dårligt belagt deres islamanalyser er, ved at pynte dem med, at de er "politisk ukorrekte" - som om denne grandstanding i sig selv gør dem mere rigtige. Sagen er, at ingen islamforsker benægter, at jihadisme har noget med 
islam at gøre - selv har jeg skrevet om jihadistiske islamtolkninger i henved 30 år - men det er den slags, vi får skudt i skoene af de mest anti-muslimske bloggere. Men for os er det ikke et skridt frem at diskutere, om islam selv er voldelig. Det er et skridt tilbage. Fordi det endnu engang fjerner fokus fra solide undersøgelser af vores egentlige objekt: muslimer. Hvorfor den muslimske verden står, hvor den står, hvad muslimske teologer og lægmænd diskuterer, hvorfor jihadismen blomstrede op, og hvor jihadisterne og deres mange muslimske modstandere er på vej hen. Men det er også et skridt tilbage i den forstand, at postulatet om islam som ufredens religion giver jihadisternes tolkning alt for megen kredit.

\section{Thomas Hoffmanns svar til Jakob Skovgaard- Petersen, postet på Facebook, 17. juni 2017}

Mine lovede 5 cents. Here goes: For det første et par bemærkninger til udtrykket "ufredens religion". Det er naturligvis virkeligt godt, at mange muslimer i dag forstår "islam" som "fredens religion", baseret på en sproglig forbindelse til ordet "salam", som betyder fred. Men der er også elementer af historieløshed i denne nytolkning: Dels refererer det arabiske ord "islam" primært til "underkastelse" og kobler sig til en stærk tematik om at underkaste sig og adlyde den suveræne Gud (mest ikonisk og rituelt i tidebønnens koreografi). Dels er der ikke nogen - så vidt jeg ved - af de klassiske eller tidligt moderne eksegeter, der forklarer ordet "islam" som "fred", men derimod peger på enhedstanken, anerkendelse af Guds love, lydighed og hjertets underkastelse. Hvis et vægtigt tekststed kunne fremgraves, ville jeg gerne se det. For så vidt at islam faktisk også kan referere til fred i sin rod, skal vi huske på det gammelorientalske "fredsbegreb", som egentlig var alt andet end fredeligt. Her handlede freden ikke mindst om at vinde "freden" i krigen, dvs. at få overmagten (Johannes Pedersen skriver klassisk om det i sin Israel-bog).

Nuvel, fredtolkningen er ved at vinde frem - men jeg gætter også på, at det dels skyldes, at islam netop i disse år bliver skudt krigeriskhed i skoene. Og som sådan er det også tale om en slags defensiv reaktion frem for et paradigme, der så at sige er opstået på eget initiativ. 
Mht. mange muslimers (og ikke-muslimers!) afvisning af jihadisme forekommer det mig for enkelt at sige, at paroler som "islam er fred" er ren terrorfordømmelse og ikke virkelighedsfornægtelse. Dels hænger det ikke helt sammen med de forskellige islamistiske bevægelser rundt om i verden, der benytter sig af terrorisme som asymmetrisk kampmiddel, og som fortfarende får støtte fra lokalt, regionalt og globalt hold. Dels hænger det ikke helt sammen med de stærke strømninger i den muslimske verden, som måske nok specifikt beklager terror, men samtidig også (bort)forklarer det som et uundgåeligt fænomen pga. en lokal, regional eller global (især vestlig) fjendtlighed eller undertrykkelse. Analysebureauet Pew har jo nogle ret foruroligende tal på sympatien for disse bevægelser. Og selv hvis vi tager det militante ud af ligningen, har vi stadig nogle dybt illiberale strømninger (jf. Inglehart \& Norris, Pew, Koopmanns m.fl.). Her vil jeg gerne påpege, at rigtigt mange ikke-muslimer også abonnerer på dette perspektiv (bare ét klassisk eksempel: den danske tv-vært, der kom til at ytre, at med 9/11 fik amerikanerne nu, hvad de selv havde lagt op til). Nå ja, Israel-Palæstina-konflikten spiller også ind. Den genererer fortfarende højst ambivalente attituder. Jeg tænker f.eks. på al-Qaradawis (m.fl.) fordømmelse af selvmordsangreb på civile - med undtagelse af Israels.

Mht. Obamas og Bushs italesættelse af islam som fredens religion, tolker jeg blot dette som udtryk for dét, Platon vistnok kaldte for "ædle løgne”. Politikerens job par excellence er jo at sikre den offentlige orden ved at pushe myter. Don't rock the boat! Det er jeg enig i. Vi lever af og i myter i vores samfund, men ikke når vi prøver at diskutere på et lidt mere analytisk plan. For øvrigt gennemskuede mange Obamas smukke ord og slog ned på, at han trods alt har været en super-dronende præsident.

Jakob, du skriver: "Det er ikke vores opgave at fastslå, at islam er fredelig eller voldelig." Nej, det er klart ikke vores opgave på så sort-hvide enten-eller præmisser. Alligevel fastslår vi religionsforskere konstant, at denne eller hin religion er befordrende for visse attituder og handlingsdispositioner, tænk bare på Webers (måske fejlagtige men alligevel vigtige) teser om protestantismes sammenhæng med kapitalismens fremkomst. At nogle religioner og religionstyper udviser visse socio-politiske tendenser, der ganske vist ofte kan være højst paradoksale, 
tænk f.eks. på apokalyptikken, der kan befordre kvietisme og tålmod, men også det stik modsatte i form af mahdi-bevægelser og IS-agtig aktivisme. Så, jo, det er faktisk vores opgave at indkredse, generalisere og predicte bestemte religionstyper, mønstre og processer - men selvfølgelig også religionerne som systemer. Så nej: Religioner er ikke kun, hvad deres udøvere tolker dem frem til - og da slet ikke, når der er en stærk tradition for bogstavtro/common-sense-agtige læsninger af Koranen. Lad mig citere fra Michael Cook (for udenforstående en højt estimeret islamforsker), som du ved, jeg finder interessant: "Naturligvis tager jeg det for givet, at det gør en forskel, hvorvidt ens religiøse kulturarv er islamisk, hinduistisk eller kristen ... Det følger heraf, at jeg ikke har nogen stor sympati for ideen om, at religiøse traditioner er kit i fortolkernes hænder - som om kulturarv kan fortolkes til at betyde hvad som helst, man ønsker, og at alle fortolkninger forekommer lige plausible for ens trosfæller."

Og så synes jeg egentlig heller ikke, at Krasnik de-legitimerer de muslimer, der afviser, at islam har noget med ufred at gøre. Han følger vel sådan set bare trop hos en lille avantgarde af muslimer, der er ekstremt (selv)kritiske over for nogle særlige problematiske elementer af den islamiske tradition hos den klerikale elite såvel som hos lægfolk. Derfor mener jeg heller ikke, at Krasnik skyder hele skylden på islam, men han insisterer blot på at indføre religionen som et vigtigt parameter. Som religionshistoriker forekommer det mig at være en fuldstændig rimelig tanke.

Mht. jihadismen som et moderne produkt, fremprovokeret af afkoloniseringen. Men det er jo langtfra kun et produkt af afkolonialiseringen, som du skriver. Vi kan tænke på wahhabismens opkomst i 1700-tallet (Saudi-Arabien har trods alt aldrig været koloniseret) - og talrige andre militant-puritansk-reformistiske bevægelser gennem tider. Og ligeledes tænke på jihadismen som vestens utilsigtede skabelse/intensivering, da den støttede mujahedinerne i kampen mod Sovjet, dvs. et forsøg på at hjælpe muslimerne. Det var ikke afkolonialisering, men snarere et forsøg på at hjælpe muslimerne/afghanerne i Afghanistan med deres egen stat (som for øvrigt heller aldrig har kunnet overtages af nogle vestlige magter i øvrigt). Derudover: Hvordan forklarer vi så alle de (af)kolonialiserede (i Afrika, Asien og Sydamerika), der ikke tog og tager terrorismen op som våben? 
Måske har denne jihadisme så netop rigtigt meget at gøre med religionen - måske er islam den politisk mest mobiliserbare religion i forhold til alle andre religioner (og som har demografisk man power til gøre indtryk), og måske har islam dermed også alle problemerne med politisk-religiøs radikalisme. Hvorfor må religioner ikke være forskellige, som Shadi Hamid jo fint argumenterede for?

Mht. sekulariseringen. Tja, for Holocausts vedkommende kan jeg simpelthen ikke se, hvordan kristendommen (og kristne) ikke også bærer en stor skyld. Eller Luthers skyld(spart) apropos 2017. Men hvad så da med Gulag og Maos Kina, som var ateistiske? Sandt nok, men det var kommunismen som en utopisk ideologi, der kan ligne millenarisme i sit historiesyn og som sådan rummer religiøse træk. Men vigtigt af alt for det 20. århundredes massakrer - med eller uden religion - er vel udviklingen af den moderne teknologi og nationalstat, som skabte alle tiders mest effektive dræbermaskiner (gennemtestet på Europa 1914-18), eksporteret og importeret til resten af verdens nationer, der taknemmeligt tager imod (jf. de verserende sager om våbenhandler på halvøen).

Ok, der er mere, der kan siges, men nu er klokken mange. Men helt grundlæggende mener jeg ikke, at Krasniks leder er problematisk, men derimod et udtryk for en vilje til at engagere sig i de mere ømtålelige problematikker, der knytter sig til dette felt og vores tid. Det må selvsagt formuleres journalistisk, fordi Krasnik først og fremmest er journalist og redaktør og derfor ikke altid flugter vores forskningsbaserede forbehold og nuancer.

\section{Jakob Skovgaard-Petersen:"Er islam ufredens religion? 2", postet på Facebook, 1. juli 2017}

Tak til Thomas Hoffmann for at rejse en række spørgsmål til min kommentar til Krasniks leder om islam som ufredens religion. Jeg lovede at svare efter eksamen, som nu er slut. Thomas' tekst er ret lang, så mit svar når også op på en vis længde. Jeg vil stadig gerne diskutere det live med Krasnik, og også med Thomas, men foreløbigt bliver det altså her, samlet om de punkter Thomas tager op.

A. Fredens religion. Thomas finder, at forbindelsen af disse 
ord er en ny tolkning, en reaktion på, at man i Vesten siger det modsatte, og han vil gerne se et vægtigt tekststed, der nævner det. Jeg mener, det er gennemgående i klassisk muslimsk politisk og juridisk tænkning, at hvor islam råder, er der fred. Ordet fred, salam, og islam er sprogligt nært beslægtede, og det er ikke etymologi eller noget, man skal være lærd for at vide. Man skal bare tale arabisk. Så det er brugt i digte, af historikere osv. Thomas bruger metaforen med bønnen, hvor man underkaster sig Guds vilje ved at bøje sig ned. For at blive i metaforen, så afslutter man bønnen ved at henvende sig til sine sidemænd og sige salam. Ligesom muslimer skal hilse på hinanden med et "salam være med dig". Kaliffen skulle sikre denne fred (salam, aman) i det muslimske territorium, hvorfor han residerede i "Fredens by". Krigens territorium var netop det modsatte af der, hvor islam rådede. Det var selvfølgelig langt fra altid tilfældet, at der faktisk var så fredeligt, men i perioder var der, og karavaner kunne rejse langt under den samme fred og jurisdiktion. Det var i hvert fald den teoretiske lære, og strid mellem muslimer, fitna, var voldsomt fordømt. Islam og fred var så tæt associerede, at udtrykket "fredens religion" i det 20. århundrede blev opfattet som plausibelt af mange muslimer, netop som Michael Cook fordrer i Thomas' citat. Det er ikke historieløst af muslimer at have en sådan tolkning. Jeg minder lige her om, at det altså ikke er mit eget synspunkt som forsker, at islam er fredens (eller ufredens) religion.

Jeg vil til gengæld tilslutte mig Thomas' pointe om, at den fred, vi her taler om, var en pax islamica, muslimernes fred. At deltage i krig for at udvide islams territorium var fortjenstfuldt - selv om det i væsentlige dele af muslimsk historie gik i glemmebogen, og man havde fredelige udvekslinger med ikke-muslimske nabo-territorier og fyrster. Salam var fred, på Guds og muslimernes betingelser. Ikke pacifisme.

Her er et vægtigt tekststed, der taler om islam som "fredens religion": "Det må nu stå klart, at eksistensen af det arabiske sprogs betydning ligger $i$, at det er islams sprog, uden hvilket muslimerne fra de forskellige folkeslag ikke ville kunne udgøre en enkelt umma, sådan som Koranen foreskriver. Ej heller kunne deres individer være brødre, sådan som Koranen beskriver dem. Beviset ligger $i$, at [disse udviklinger] faktisk er indtruffet, samt $i$, at islam kan stå blandt de største principper for menneskelig reform. For islam er fredens religion, en forening af 
hele menneskeheden, en kur og beskyttelse imod fjendskab og had mellem menneskene ..." Dette er ét citat af mange mulige fra de muslimske reformister, der fra slutningen af 1800-tallet reformulerede, hvad man skulle forstå ved islam. Dette specifikke citat er fra 1932 af Rashid Rida, ofte kaldet den mest indflydelsesrige sunnimuslimske tænker i det 20. århundrede, fra tidsskriftet al-Manar, der blev læst fra Dakar til Jakarta. ${ }^{2}$ Tre år senere kom den vigtigste biografi om Muhammad i det 20 . århundrede, af Muhammad Haykal, som også fremstiller ham som en fredens forkæmper, der afskyede vold. De her folk er ikke marginale; de er helt centrale; deres tekster ligger til grund for skolesystemernes behandling af islam, for Muhammad på film og i massemedier osv. At deres forståelse af islam, som alt andet i den muslimske verden, på en direkte eller indirekte måde er en respons på europæisk modernitet, det giver sig selv og gør det ikke mindre betydningsfuldt. Sådan har udviklingen været i alle religioner. Det lader i øvrigt ikke til, at det store flertal af danske debattører, der dagligt skriver om islam, har læst eller bare hørt om Rida eller Haykal, og det er med til at gøre deres skriverier om manglende oplysningstid så uoplyste.

B. Sagen er, at hele den klassiske tankeverden om en verden opdelt i dar al-islam (islams territorium) og dar al-harb (krigens territorium) blev opbrudt i moderne tid, hvor territoriale stater i teorien lever i fred med hinanden og er medlemmer af de Forenede Nationer etc. Saudi-Arabien, så grotesk landet er på mange måder, er også en del af det mønster; dets første traktater var netop med briterne og amerikanerne, altså ligefrem kuffar (de vantro), og de wahhabier, der ikke forstod og accepterede det, fik Ibn Saud undertvunget. Det er den væsentlige ramme for de seneste mange generationer af muslimsk liv. Jihad er blevet fortolket derefter. Store lærde fastslog, at muslimer i udgangspunktet lever i fred med deres naboer og kun skal gribe til våben, hvis de bliver angrebet. Det gælder f.eks. Mahmud Shaltut, den mest beundrede Shaykh al-Azhar i det 20. århundrede, hvis tekst man vil kunne finde i Ruud Peters' tekstsamling om jihad, der er oversat til dansk.

Nytolkningen af islam som fredens religion er altså ikke sket, som Thomas skriver, nu her som reaktion på voldelige jihadister. Det er omvendt: Det er radikale islamistiske ideo-

2. Rashid Rida. 1932. al-Manar 32: 537 . loger som Nabahani og Qutb, der under afkoloniseringen har reageret på det moderne interstatslige system og afvist disse 
nye tolkninger af jihad og fredelig sameksistens. Sammen med andre positioner som afvisningen af parlamentarisme, brugen af takfir (kætterstempling), påstanden om jihad som en sjette søjle, ophøjelsen af selvmordsaktioner som martyriet mv. udgør det ideologien i moderne jihadisme. Den har forløbere, som jeg skrev, netop med henblik på wahhabismen. Men der vil være bred konsensus om blandt forskere, at den tager form under afkolonialiseringen i anden halvdel af det 20. århundrede. Så uenige Kepel og Roy er på andre områder, er de det ikke her. Thomas' argumentation med, at wahhabitterne er før-koloniale, lyder, som om han i ordet afkolonisering hører noget moralsk, en tildeling af skyld til kolonialismen. For os mellemøstforskere er det bare en epoke, fra 1945 til 1970. Så langt fra at bebrejde kolonimagterne er det netop at fastslå, at moderne jihadisme hører hjemme i perioden, efter de forlod regionen: Det er netop, da muslimerne ikke længere har kolonimagten at stå sammen imod og bliver "alene hjemme" i deres egne stater, at konflikten til magthaverne skærpes, og de islamistiske bevægelser - sunni og shia - i f.eks. Egypten, Syrien og Irak splittes op i ikke-voldelige og voldelige, hver med sin ideologi, at egentligt jihadistiske grupper fremkommer. De kan trække på tidligere begreber og tanker, men de tilføjer også deres eget i en helt ny verden og kontekst. Så jeg står ved min formulering og regner den for temmelig ukontroversiel.

Når en formulering som "fredens religion" først dukker op i det 20. århundrede, hænger det sammen med det, man har kaldt reificeringen (tingsliggørelsen) af islam: I ældre tider var islam en betegnelse for verdens orden og ikke noget, man sådan trådte tilbage fra og karakteriserede. Det er pointen i Wilfred Cantwell Smiths store undersøgelse af muslimske teksters anvendelse af termen islam. Det bliver derfor først rigtigt muligt i og med mødet med det 19. århundredes europæiske opfattelse af, at verden består af et mindre antal civilisationer, hver skabt af en religion. Som nu altså kan abstraheres som muslimernes historie og karakteriseres med tillægsord. At tænke på islam som en sum af muslimernes historie og erfaringer er altså en ny måde for muslimer at tænke på islam i moderniteten. Europæerne skrev i 1800-tallet om det med tidens store fremtidstro: Europas civilisation var alle andre overlegen, og beviset kunne alle se. Efter første verdenskrig var det argument i laser: Det krigstrætte Europa stillede spørgsmål ved sin egen 
civilisatoriske fortræffelighed, og det gjorde man selvsagt også i kolonierne. At muslimske tænkere nu over en bred kam kunne fremhæve islam som "fredens religion", et offer for det aggressive og imperialistiske Europa, var både oplagt og plausibelt.

Wilfred Cantwell Smith peger også på noget vigtigt om vores brug af ordet islam, som jeg synes, vi hele tiden går galt i. Nemlig at vi benytter ordet islam på tre ret forskellige måder:

a) som en civilisation (altså den "muslimske verden", med alt hvad muslimer har gjort og gør; det er den benyttelse, der slår igennem i 1800-tallet med formuleringer som " $i$ islam");

b) som et læresystem (om skabelse, engle, dom, jihad, halal og haram mv);

c) som den enkelte muslims tro.

Uheldigvis blandes disse niveauer sammen. Det er, hvad Krasnik gør, når han mistolker de enkelte muslimers personlige udsagn om, at islam er fredelig, som en benægtelse af, at der finder vold sted begået af muslimer i islams navn (hvad langt de fleste udmærket er klar over). Så ender vi i en slags catch-22 for danske muslimer, som på den ene side får at vide, at de skal tage afstand fra terror (som de derved må acceptere at associere sig med, a la "slår du stadigvæk din kone?”), og på den anden side, at denne selv samme afstandtagen er virkelighedsfornægtelse. Det er vel også en form for sammenblanding, når Thomas mener, at "mange har gennemskuet" Obama, når han kaldte islam en fredelig religion, samtidigt med at han bombede jihadister. Obama var ikke inkonsistent; han talte om islam som læresystem, ikke som civilisation. Og han talte som statsmand i et bestemt ærinde. Det var dem, der mente at gennemskue, som ikke kunne sondre mellem disse forskellige måder at omtale religion.

Muslimer er i deres gode ret til at forstå deres religion som fredens religion og afvise voldelige fortolkninger som uislamiske. Ligesom jeg som kristen i min ungdom var i min gode ret til at afvise sydafrikanske præsters opfattelse af apartheid som sand og konsekvent kristendom. Havde jeg derimod været kirkehistoriker eller religionsforsker, måtte jeg som fagmand konstatere, at dette var endnu et skud på kristendommens eller kristenhedens vidtforgrenede stamme. Og som islamfor- 
sker må jeg rumme alle disse dimensioner og studere bestemte muslimske gruppers og menneskers tro, læresystemer og faktiske bedrifter.

Det bringer mig til de muslimer, der ikke mener, at islam har noget med ufred at gøre. Thomas synes ikke, at Krasnik de-legitimerer dem. Det synes jeg, han gør, i sin overskrift og i sin tekst, og reaktionerne på min tekst fortæller mig, at det synes mange danske muslimer også. Krasnik skriver, at de lukker øjnene og ønsketænker, mens jeg siger, at de markerer deres afstandtagen fra voldelige tolkninger af islam, af jihadister og af os andre. Inklusive enkelte muslimske debattører, som også fordømmer "islam" selv, vil tage vers ud af Koranen eller lignende. Er det mon dem, Thomas henviser til, når han taler om "en lille avantgarde af muslimer, der er ekstremt (selv) kritiske over for nogle særlige problematiske elementer af den islamiske tradition"? Og som er dem, han synes, at Krasnik solidariserer sig med? Her vil jeg skelne mellem folk, der som Ayan Hirsi Ali simpelthen fordømmer islam som voldelig og præmoderne og ikke udtrykker nogen positive følelser over for religionen, og så muslimske tænkere som Nasr Hamid Abu Zeid, der kommer på kollisionskurs med religiøse og politiske grupper, men som arbejder med islam som deres egen religion og ser den som retningsgivende i deres liv. Jeg har vanskeligt ved at se, hvordan man solidariserer sig med den sidstnævnte kategori ved at kalde islam for "ufredens religion". Som jeg forklarede, pågår der en kulturkamp om islam i den muslimske verden med en række forskellige positioner. F.eks. i spørgsmål om kvinders og mænds ligestilling. Den føres normalt mellem muslimer, der opfatter islam som vigtig i deres liv, men mange andre muslimer tænker mindre over disse emner, uden at de opfatter sig som ateister af den grund (selv om ateisterne også findes). Alligevel vil de fleste muslimer nok ikke benægte, at der begås voldshandlinger i islams navn. De skriver og taler i alt fald om det i arabiske medier hver dag.

$\mathrm{Nu}$ er det imidlertid også muslimer, der mener, at islam ikke bare er voldelig selv, men skal være det. Det er jihadisterne. I det store billede er de ikke mange, men hver og en er for mange. Alle de andre kan have deres normer og fortolkninger, som ikke lever op til vore danske normer om homoseksualitet, ligestilling eller hvad det nu måtte være. Men de opfatter ikke islam som ufredens religion, og de opfatter jihadisterne som 
uislamiske. Det er med andre ord ikke en lille avantgarde, som vi kan betragte som bona fide. Det er en overvældende stor gruppe mennesker, hvis religiøse synspunkter i lige så høj grad fortjener at blive taget alvorligt som jihadisterne. Krasnik "insisterer blot på at indføre religionen som et vigtigt parameter," siger Thomas; men det er netop det, jeg synes, han ikke gør. Han blander nogle påstande om, hvad "islam siger", sammen med jihadistiske angreb og nyere mellemøstlige ulykker til "islam". Men hvis man ikke tager religionens udøvere alvorligt, tager man ikke religionen alvorligt.

C. Om at bringe religionen ind. Thomas vil meget gerne "bringe religionen ind". I virkeligheden synes han at mene, at der er bevæggrunde, som ikke lader sig reducere til materielle faktorer. Det er jeg ganske enig i, men det er ikke det samme som religion. For når han også gør kommunisme til en form for religion, bliver religionen snarere udvandet end bragt ind, synes jeg. Og religion er ikke vel defineret. Thomas skriver: "Så nej: Religioner er ikke kun, hvad deres udøvere tolker dem frem til." Det er da også rigtigt, at religioner har en historie, inklusive en juridisk og teologisk historie, som jeg faktisk beskæftiger mig med. Religioner kan beskrives på mange måder - som jeg lige har været inde på - og de har institutioner, skrifter, præsteskaber, ritualer og alt muligt andet. Men jeg vil mene, at hvis det drejer sig om at forstå muslimer i dag, så er det netop deres fortolkning af islam, vi skal koncentrere os om - foruden deres fortolkninger og handlinger på alle mulige andre områder af livet. De står med traditioner, institutioner, skrifter, sprog og begreber. Og de vil gerne forstå dem og føre dem videre til deres samtid og efterkommere. Det gør de som regel også, men ikke uden en del forskydninger - bevidste og ubevidste - ikke mindst i vor tid. Hvilket er præcist, hvad en religionsforsker med speciale i nutidig islam som mig skal arbejde med. Hvis man skal forstå nutidige muslimer - og det er dem, Krasnik skriver om - skal man forstå, hvordan de fortolker verden, Gud, loven og alt muligt andet. Med vægten lagt på de seneste generationer, selvfølgelig, ligesom hvis man skulle forstå jøder, buddhister eller franskmænd.

Thomas refererer til Weber som en forsker, der netop påpegede betydningen af de troendes religiøse holdninger for deres handlinger. Rigtigt. Men det var også som kritik af 1800-tallets religionsforskning, der mente, at folk var styret af skrift og te- 
ologi. I stedet satte Weber begrebet om en handlingsorienteret etos og påpegede, at den er båret af bestemte grupper inden for religionen. Dermed var en dynamisk religionssociologi født, og religion blev nu anskuet som en foranderlig og socialt båren størrelse. Det er netop, fordi jeg studerer en sådan bærergruppe, de muslimske lærde, at Krasniks generalisering giver så lidt mening. Den samme teologi kunne, som Thomas jo også påpeger, ofte føre til paradoksalt forskellige etos'er i forskellige grupper. Ligesom selve tesen om den protestantiske etik går ud på, at den fik nogle konsekvenser, som reformatorerne ikke i deres vildeste fantasi havde forestillet sig, og uden tvivl ville have fordømt. Etos udledes ikke af skriften, men af de troendes senere forståelser. Det skulle en eller anden behjertet sjæl eller bare habil faghistoriker forklare de teologer og idehistorikere, der ser Luther som udgangspunkt for alt godt eller ondt i Nordeuropa sidenhen. Jeg har undervist flere kurser i Weber og islam og vedlægger et link til en kritik af, hvad jeg mener er alt for forenklede anvendelser af weberianisme.

Det er dristigt af Thomas at tænke sin religionsforståelse ud i sin konsekvens og konkludere, at kristendommen "bærer en stor skyld" i holocaust. Hvis Krasnik er enig, burde det vel føre til, at han skrev en leder om kristendommen under titlen "Folkedrabets religion"?

For mig giver denne type religiøs determinisme imidlertid ikke megen mening som weberiansk argument. Vi kan godt undersøge holocaust-bødlernes bevæggrunde, og om nogle af dem opfattede det som en kristen gerning, men det er ikke som sådan "bevirket" af kristendommen - akkurat som vold heller ikke er i det islamiske tilfælde. Med fare for at få skudt i skoene, at jeg "negligerer religionen som et vigtigt parameter", vil jeg mene, at andre faktorer indgår langt mere prominent $i$ holocaust. Når jeg nævnte, at de værste folkemord i historien ikke er begået af muslimer, men af bl.a. kristne, var det ikke for at sige, at kristendommen er en voldelig religion. Den generalisering vil jeg lave lige så lidt som den om islam. Det var heller ikke for at sige, at muslimer ikke vil begå massemord, fordi islam er fredelig. Det kan de desværre godt, som vi ser i disse år. Det var derimod slet og ret for at minde Krasnik om en passende selvbesindelse, når vi udråber andre religioner til at være "ufredens", men frikender vore egne for et sådant generaliserende prædikat. Når Thomas undskylder generaliserin- 
gen med, at Krasnik er journalist og derfor ikke ved bedre, er jeg igen uenig. At kalde islam for ufredens religion flugter ikke med mine forventninger til en lederskribent i en toneangivende avis, netop emnets alvor taget i betragtning.

Jeg håber, det står klart, at jeg ikke siger dette, fordi jeg “ønsketænker", er "politisk korrekt" eller ikke vil se problemerne i øjnene. Det har Thomas nu heller ikke på nogen måde antydet. Jeg har netop skrevet mit svar på Krasniks leder, fordi jeg synes, vi skal se problemerne i øjnene dér, hvor de er. Hverken jeg eller mine kolleger benægter, at jihadistisk vold har noget med islam at gøre - det er en typisk stråmand at hævde, at vi gør det. Vi ser bare ikke nogen god grund til at privilegere voldelige tolkninger af islam som de sande. Martin Krasnik, Thomas Hoffmann, jeg selv og andre journalister og forskere har en stor opgave i at afdække og forstå, hvordan jihadismen fungerer, hvordan den fortolker, hvorfor den appellerer til nogle, men i lige så høj grad hvorfor den slet ikke appellerer til det store flertal. Samtidigt har talløse muslimer i Danmark og udlandet en fælles opgave i at afvise og bekæmpe jihadistiske tolkninger af islam. Lad os ikke tabe det mål af syne.

\section{Thomas Hoffmann: “Genmælet, der aldrig blev postet"}

Som hurtig replik til dit svar til mig skrev jeg, at dét ville jeg læse grundigt og tænke over. Det har jeg så gjort nu. Jeg håber, at du vil værdsætte mine overvejelser og indvendinger til dine ditto, for jeg tror, at du misforstår nogle af mine pointer. Meget er vi jo faktisk enige om: historiens og kontekstens vigtige rolle, fortolkningernes omskiftelighed og kreativitet, kort sagt alt det allzumenschliches. Vi kan også være enige om, at determinisme ikke fungerer særligt godt som forskningshypotese, ligesom vi også er enige om, at teologi og metafysik tæller og ikke kan reduceres til rene materielle faktorer. Men vi er måske nok uenige om, hvor meget de vægter, og hvad man stiller op med dem.

Jeg begynder.

Fredens religion. Helt overordnet synes jeg, at du negligerer de forbehold, jeg indsatte i min første 5 cents-replik mht. islam/salam/freds-forbindelserne. Du skriver: "Muslimer er i deres gode ret til at forstå deres religion som fredens religion og 
afvise voldelige fortolkninger som uislamiske." Men det skrev jeg faktisk også som noget af det allerførste i min kommentar. Jeg skrev således, at det var "virkeligt godt, at mange muslimer i dag forstår 'islam' som 'fredens religion'”. Med andre ord: Jeg anerkendte og anerkender fuldt ud de troendes (ny)fortolkninger. Dét, jeg problematiserer, er historiebevidstheden.

Med hensyn til at "fredshilsenen" i bønnen kan fremføres som et bevis på den dybe fredsrod, så er det en god observation. Men som du også selv i enighed med mig skriver, så er der tale om en pax islamica, dvs. en fred på islams betingelser. Her "afslører" fredshilsenen sig også, for ligesom pax islamica er den jo formelt set kun forbeholdt trosfæller, ikke bare i bønnen naturligvis, men i det levede livs omgang med ikke-muslimer. Et salam alaykum til ikke-muslimen frarådes således tit i forskellige manualer og på internettet, f.eks. en populær dansk Q\&A/fatwa-side som islamsvar.dk. ${ }^{3}$ En detalje, men en djævel i detaljen.

Med hensyn til det forhold, at jeg skulle bebrejde nutidens muslimer for historieløshed, så skriver jeg faktisk ganske forsigtigt, at der er "elementer af historieløshed". Med andre ord giver jeg ikke udtryk for en total generalisering. Historieløshed er ikke et unikt muslimsk fænomen, men findes i alle samfund og kulturer, inklusive Vestens, så dét synes jeg egentlig ikke er et kontroversielt udsagn.

Jeg havde efterlyst vægtige klassiske skriftsteder, der kobler klassiske islam-definitioner med en eksplicit salam/freds-definition. Du kommer med et par eksempler, men de er jo netop ikke klassiske (ingen Tha'labi, Ibn Kathir, al-Zamakhshari, al-Tabari, Ibn Qutayba osv.), men tidligt moderne, nemlig Rida og Haykal m.fl., hvor man især om Rida ikke kan sige, at han oppebar en særlig fredelig indstilling til den ikke-muslimske omverden. Og dét var jo sådan set også min oprindelige pointe i mine 5 cent - det er et forholdsvis moderne fænomen og et fænomen, som især er ved at få mere momentum i disse år, ikke mindst på grund af intensiveret "jihad-bashing" (som imidlertid er lige så gammel som islam selv). Du skriver det faktisk selv: "Når en formulering som 'fredens religion' først dukker

3. islamsvar.dk/halal-og-haram/ sociale-relationer/hilse-pa-ikke-muslimer-med-qassalamu-alaykumq/ (sidst tilgået 09.07.2018). op i det 20. århundrede ..." Netop! Men så har jeg vel også ret i min pointe, at det med fredens religion er en moderne tolkning og ikke bare kan essentialiseres til en tidløs forkyndelse?

Jakob, du identificerer problematikken i dag til reifikatio- 
nen af islam og henviser til W.C. Smith. Jeg er enig i reifikationsproblematikken, men Koranen og tidlig islam er måske ganske unik ved faktisk selv at tage det første skridt til reificeringen i form af det berømte vers K 5:3, hvor Muhammad meddeler fuldkommengørelsen af religionen: "Jeg finder velbehag i underkastelsen [til Gud] som religion for jer (wa-radìtu lakumu l- 'isläma dìnan)." Jeg er helt bevidst om, at verset kan oversættes anderledes, men reifikationen ved at oversætte al-'islām som Islam med stort I (vi må lægge mærke til den bestemte artikel) flugter altså fint med Koranens slående selvbevidsthed i form af metadiskurs om sig selv, noget jeg jo har arbejdet med tidligere. Reifikation er ikke nødvendigvis en dubiøs strategi, men én måde at håndtere kompleksitet på.

Du skriver også: “Og som islamforsker må jeg rumme alle disse dimensioner og studere bestemte muslimske gruppers og menneskers tro, læresystemer og faktiske bedrifter." Jeg kunne ikke være mere enig; måske husker du vores seminar på Louisiana, hvor jeg argumenterede for, hvordan man meningsfuldt på fire forskellige måder kunne sige, at noget er islamisk, men samtidig også uislamisk. Min mundtlige præsentation kan i øvrigt genfindes i en af mine klummer i Weekendavisen under overskriften "Humpty Dumptys islam". Jeg sammenlignede det med Niels Bohrs kvantemekanik: Om lysatomerne skal beskrives som partikel- eller bølgeform afhænger af målingsmetoden. Ligeså med islamiske/uislamiske handlinger: Det afhænger af synsvinklen, ræsonnementets tilrettelæggelse, faktorer som herskende trends eller outlier-fænomener (f.eks. jihadisme), men også om gennemslagskraft og entusiasme nogle gange kan den numerisk lille gruppe være markant mere gennemslagskraftig og legitim end den brede "passive" masse, der ikke handler. Er militant jihad i dag ikke et meget godt eksempel på det?

Med hensyn til at solidarisere med kritiske muslimer: Misforstår jeg, at du antyder, at jeg solidariserer mere med Hirsi Ali end Abu Zayd? Det ville i så fald være sært, for jeg refererer sjældent specifikt til nogle af disse folk. At jeg i min ph.d.-afhandling refererede til Abu Zayd og inviterede ham til konference her i Danmark giver dog et praj om, hvem jeg har haft høje tanker om.

4. Weekendavisen, Ideer-sektionen (03.07.2015).
Tilbage til jihadisterne! Du skriver, at der er en "overvældende stor grupper mennesker [...] som betragter jihadisterne 
som uislamiske." Ja da, men så synes jeg, at du underbetoner de intrikate forbindelser, "glidebaner" og deciderede kontradiktioner, der er mellem jihadisme og islamisme, militant og/ eller ikke-militant, mellem islam, der er fredelig lokalt, men støtter og solidariserer med forskellige jihadistiske bevægelser (eller irredentistiske grupper). Her har jeg blandt andet været inspireret af en artikel af Jillian Schwedler, "Can Islamists Become Moderates? Rethinking the Inclusion-Moderation Hypothesis", som jeg så også reflekterede på i endnu en klumme i Weekendavisen. ${ }^{5}$

Endelig fremfører du, at ingen fagfolk "benægter, at jihadistisk vold har noget med islam at gøre - det er en typisk stråmand at hævde, at vi gør det. Vi ser bare ikke nogen god grund til at privilegere voldelige tolkninger af islam som de sande." Det er nok her, at vi er mest uenige: Som religionsforskere med islam som speciale giver det jo netop mening at privilegere de voldelige tolkninger af islam - naturligvis ikke som sande, men som effektfulde under de rette omstændigheder. Og naturligvis heller ikke som de eneste tolkninger, men dog som nogle af de mere vægtige og indflydelsesrige. En vending som "voldelig tolkning" nedtoner derudover helt urimeligt udsagn og tendenser i litteraturen, der ikke bare er tolkninger, men i sig selv er voldelige og kredser om voldens gestaltning. Snarere må vi vel tale om, at det er de voldelige passager og opfordringer, som igennem historien er blevet omfortolket eller negligeret $i$ sameksistensens pragmatiske tjeneste, f.eks. når hinduer ikke blev klassificeret som flergudsdyrkende kuffar, men en slags monoteister.

$\mathrm{Nu}$ slutter jeg med en sidste replik, der er ude i samme kontrafaktiske tænkning, som du selv afslutter med. Tjo, jeg tror såmænd godt Krasnik kunne have skrevet en leder om kristendommen under titlen "Folkedrabets religion", hvis det handlede om middelalderens kristne persecuting society, ikke mindst med henblik på jøderne, men vi kunne vel også nævne indianerne i Amerika. Men nu er det jo et nyhedsmedie, Krasnik står for, og ikke et historisk tidsskrift. Selvfølgelig lå hele skylden ikke på det Nye Testamentes stærke anti-judaisme, men min pointe var jo også blot den, at religionen med dens

5. "Moderationens svære kunst", Weekendavisen, Ideer-sektionen (27.01.2012). grundtekster, dens arkiver og repertoirer (f.eks. en vældig stor juridisk jihad-tænkning) ikke udgør den eneste faktor, men så sandelig heller ikke en uvæsentlig sådan. 


\section{Jakob Skovgaard-Petersen: "Er islam ufredens religion? Et svar til Thomas Hoffmanns replik"}

Tak for dine kommentarer. Du lægger ud med at sige, at meget er vi enige om: historiens og kontekstens vigtige rolle, fortolkningernes omskiftelighed og kreativitet, at determinisme ikke duer som forskningshypotese, samt at teologi og metafysik også kan have betydning. Ja, her er vi enige. Men vi er så til gengæld ikke enige med Krasniks overskrift eller argument, som netop gik ud på, at islam i sig selv er ufredens religion, og at de muslimer, der tror på og hævder, at den er fredens religion, er virkelighedsfornægtende.

Du er også meget large over for Krasnik, som du siger ikke skriver i "et historisk tidsskrift". Men samtidigt bebrejder du de muslimer, der opfatter islam som fredens religion, for manglende historiebevidsthed (eller elementer deraf). Jeg synes, det må være omvendt. Dels kan og må man jo godt tro på en gud og sin religion uden at have den store historiebevidsthed. Dels bør vi forvente, at Krasnik ved mere om islam og Mellemøstens historie, end tilfældet åbenbart er, hvis han vil skrive ledere om emnet i en vigtig avis. Det er jo som sagt ham, der undervurderer muslimers bevidsthed, når han skriver, at de er virkelighedsfornægtende og enten ikke er klar over, eller ikke tør indrømme, at jihadistisk terror begås i islams navn. Det er helt forkert.

Vi to har også en noget forskellig opfattelse af historien. Jeg mener i min tekst at have givet mange gode eksempler på, hvor vigtigt ordet salam var i den muslimske historie, og hvor tæt knyttet det var til ordet islam. Vi er enige om, at det var en pax islamica, fred på muslimernes betingelser (ligesom det $\mathrm{i}$ Europa, i det omfang der var fred, var på de kristnes betingelser). Men at en vis gruppe muslimer mente, at salam 'alaykum ikke skulle siges til ikke-muslimer (hvilket andre muslimer altså netop gjorde) er intet argument for, at islam var ufredens religion. For der var også fred med de beskyttede folk, der boede i muslimernes territorium. Selv ikke-muslimer, som kom fra "krigens område", kunne få et beskyttelsesbrev, aman, så de kunne rejse i fred blandt muslimerne.

Fred blev altså set som et stort gode i de faktiske relationer. Det var noget andet i teorierne. Men selv der ser det ikke nødvendigvis så krigerisk ud. Faktisk er det, du kalder den "vældigt store juridiske jihad-tænkning" i klassisk tid mest optaget af, 
hvilke regler der gælder for en person, der kommer fra "krigens territorium", og for en muslim, der omvendt rejser eller bosætter sig uden for Dar al-Islam. Yohanan Friedmann har bemærket, at vi ikke har nogen klassisk islamisk juridisk tekst, der ser "krigens territorium" som et sted, der gennem krig skal inkorporeres i Dar al-Islam. Det skal vi op til Mawdudi og Islamisk Stats propaganda for at møde (Friedman 2017, 344). Det er ikke for at idealisere den islamiske historie og sige, at muslimer og ikke-muslimer (eller muslimer indbyrdes) levede med hinanden som løven og lammet. Men det er for at sige, at der i lange perioder var nogenlunde fredeligt og en form for retsorden - og at det var idealet. Så den idé, som for tiden er på mode i anti-muslimske kredse, at muslimer aldrig har kunnet, og aldrig vil kunne, leve fredeligt med andre, er historisk forkert.

Den store forskel fra middelalderens politiske verden til vore dage er tilblivelsen af moderne territoriale stater i det 19. og tidlige 20. århundrede. Det skete i Mellemøsten gennem den europæiske kolonisering, som var krigerisk og voldelig. Muslimer satte sig til modværge, somme tider under feltråbet jihad. Det hjalp dem ikke. Da besættelsesmagten var etableret, opstod der store nationale befrielsesbevægelser, ofte med en betydelig kristen deltagelse. Her var Rashid Rida prominent. Han ledte den Syriske Nationalkongres i 1920, hvor kristne og muslimske delegerede udarbejdede en liberal forfatning for alle syrere. De blev nedkæmpet af franskmændene nogle måneder senere. Det er således ikke fair, når du om Rida skriver, at han ikke "oppebar en særlig fredelig indstilling til den ikke-muslimske verden”. Rida ville gerne leve i en syrisk nationalstat med lige rettigheder til alle og i fred med nabostaterne. Han, og de fleste med ham, var anti-imperialister og støttede derfor f.eks. osmannernes kamp imod den italienske besættelse i 1911. Det har vi forståelse for i dag. Det var jo Europa, som udløste mange ekstremt brutale koloniale krige og to verdenskrige. Og alligevel talte og skrev samtidens europæiske intellektuelle (herunder min oldefar) om "islamitisk fanatisme". Det er ikke sært, at muslimske tænkere som Haykal og Rida så det anderledes og betonede, at islam var en fredselskende religion. Det har som nævnt været en dominerende tolkning i godt og vel 100 år, og som de muslimer, der siger det, typisk har hørt fra barnsben, $\mathrm{i}$ familien og i skolen. Hvor mange generationer skal der gå, før det ikke skal afvises som en "nyere" eller "apologetisk" tolkning? Efter anden verdenskrig kunne vi europæere omsider 
indse, at det var os, der havde været de militaristiske. Denne elementære historiske bevidsthed synes desværre at have fortaget sig, men dét, den burde lære os, er ikke, at vi nødvendigvis er militante, og andre folkeslag nødvendigvis er fredelige. Men at alle kulturer og religioner har potentialer til vold og til fred. Og at ingen ting derfor er tilstrækkeligt forklaret ved at henvise til et skriftsted eller et begreb.

Det er ikke dét, Krasnik skriver. Han skriver, at islam er ufredens religion. Slet og ret. Og ingen anden. Krasnik har ikke skrevet om jødedommen på den måde, selv om der er voldelige bosættere nok, der legitimerer deres vold med religiøse argumenter. Her er der en oplagt ubalance. Men for mig er problemet dog først og fremmest selve hans forståelse af religion som en slags kernebudskab, der styrer folks liv og har bevirket de forskelle i verden, vi ser i dag. Du foreslår, at han om kristendommen kunne have skrevet en leder om "folkedrabets religion", hvis det drejede sig om middelalderens forfølgelser af jøderne. I mine øjne havde denne hypotetiske middelalderlige leder været lige så forkert, hvis den fastslog, at det er kristendommen, der siger, at jøder og indianere skal slås ihjel, og at de kristne, der siger, at deres religion er fredens religion, er virkelighedsfornægtende.

Tilbage til jihadisterne!, som du siger. Du mener, at der er mange forbindelser mellem jihadister og islamister, som jeg underbetoner. Og det er jo rigtigt, at jihadismen har sine rødder i islamismen, og at begge mener, at der er en islamisk samfundsorden, som skal realiseres. Men i dag står de altså over for hinanden som fjender og bruger ganske megen tid og lidenskab på at kritisere og angribe hinanden. Jihadisterne ser krig som en grundlæggende islamisk pligt, mens islamisterne mener, at muslimer har ret til at forsvare sig selv som alle andre. Jillian Schwedlers artikel omhandler en politologisk diskussion i 1990'erne og oo'erne om, hvorvidt islamistiske partier ville moderere deres synspunkter, når og hvis de blev accepteret i det politiske liv af regimerne, så den har sådan set ikke noget med deres forhold til jihadisterne at gøre. Hun fastslår, at disse store islamistiske partier netop afsværger voldsanvendelse (bortset fra Hamas og Hizbollah, begrænset til krig imod Israel). Du nævner, at der også er muslimer, som sympatiserer med jihadister. Det er ikke så almindeligt, men det hænder, særligt hvis jihadisterne fører en kamp imod, hvad de opfatter som en undertrykkende stat som mange sunnimuslimer i Nordirak gjorde. Det, som imid- 
lertid er klart, er, at selve jihadisternes fortolkning af islam som en krigens religion, der fordrer, at man kæmper og dør, er meget lidt populær. På lignende måde skal islamisters og andre muslimers - og kristnes - støtte til Hamas og Hizbollahs kamp mod Israel ikke forveksles med støtte til bevægelsernes fortolkning af islam. I dag er denne støtte i øvrigt i det store og hele forduftet. Husk desuden på, at islamisterne stadigvæk kun er et mindretal blandt muslimerne. Shadi Hamids bog, som du roser, ignorerer alle ikke-islamistiske muslimer, når han mener, at islams traditioner gjorde den velegnet til at blive politiseret i det 20. århundrede. Det er i parentes bemærket et argument om, at det "sekulariseringens syrebad", som Krasnik tror islam ikke har mødt, netop var velgørende for religionen. Men Hamid mener heller ikke, at islam er ufredens religion. Faktisk ender bogen med, at selv islamisterne er blevet så fredfulde, at de synger og beder som en anden millenaristisk sekt, da den egyptiske hær massakrerer dem på Rabaa al-Adawiyya-pladsen i august 2013.

Vi lægger begge vægt på både tekst og kontekst. Alligevel vægter vi dem nok lidt forskelligt. Jeg er helt enig i, at kendskab til Koranen, Hadith, islamisk historie eller islamisk jura er relevant og somme tider endda nødvendigt for overhovedet at forstå, hvad nutidige muslimer refererer til og ønsker at sige. Det er jo også spændende at se, hvordan de forlænger og forandrer traditionen - en tradition de i øvrigt godt kan have et rudimentært eller direkte fejlagtigt billede af. Der kan også undertiden være en værdi i, som du nævner, at generalisere og karakterisere. Det kan f.eks. være relevant og interessant at se shiismen som "sorgens religion" og undersøge nye manifestationer af dette tema i dag. Men derfra og så til at "predicte", som du skrev, er der langt, og når vi generaliserer, skal vi huske, at vi gør det. Indtil den iranske revolution så nogle forskere shiismen som en særligt apolitisk religion, der fandt magt korrumperende og havde opgivet jordelivet. Efter revolutionen var der andre forskere, der i den så et stadigt potentiale til oprør. "Sorgens religion" kunne bruges til både det ene og det andet. Den bliver et bagtæppe, måske en dimension, eller en vinkel, vi kan anlægge. Men som forklaring kan teologien ikke stå alene. Og særligt når vi taler om samtidens mennesker, skal vi undersøge deres handlinger og motiver i stedet for at tillægge dem deres bevæggrunde på basis af en generel viden om religionens tekster og historie.

For 30 år siden var jeg på biltur med nogle syrere nord for Aleppo, og vi kom til sletten og byen Dabiq. Det optog mig, 
fordi jeg havde læst om slaget ved Marj Dabiq i 1516. Det viste sig, at ingen af mine nogenlunde veluddannede værter kendte til slaget. Noget senere opdagede jeg, at Dabiq også var et af flere steder, hvor dommedag skal finde sted, i form af et stort slag. Det vidste mine lokale værter formodentlig heller ikke, for ellers havde de vel budt ind med den historie. Der var heller intet, der belærte os om det i byen. Mange muslimer lærte først om den tradition, fordi Islamisk Stat gjorde Dabiq til titlen på deres internet-magasin. Det engelsksprogede, vel at mærke, for ellers var det nok heller ikke blevet så udbredt. I 2014 og 2015 blev jeg derfor adskillige gange ringet op af journalister, der havde læst om denne lokalitet og ville tale om IS' apokalyptiske ideologi. Jeg forklarede om traditionen, men måtte sige, at jeg ikke havde nogen anelse om, hvor vigtig den kunne være for dem. Et hint kunne man måske få i efteråret 2016, hvor tyrkiske tropper uden videre drev IS ud af byen. Dommedag var afblæst. Islamisk Stat havde ikke samlet tropper, lavet baghold eller på nogen måde ladet det spille ind, at her skulle det store slag stå, hvor Gud hjalp de troende. Siden gav de magasinet et nyt navn.

Islamisk teologi og jura er interessant, og undertiden også relevant, for at forstå, hvad folk tænker. Men som vi skrev om i første korrespondance, kom religionsvidenskaben et stort stykke videre med Webers mere sofistikerede indførelse af begrebet om en handlingsorienteret etos, som er følt og formuleret i religiøse termer, men nok så tit har været en helt uforudsigelig udlægning af religionen. Også denne etos er desuden foranderlig. Dabiq var irrelevant som politisk viden gennem århundreder. Traditionen blev gravet frem af Islamisk Stat, og øjensynligt gik den også i graven med dem igen. Men religioner er mestre i genopstandelse.

Lad mig til sidst igen minde om, at jeg ikke siger, at islam er fredens religion. Men altså heller ikke det modsatte. Selv om der altid har fandtes voldelige muslimer, og i de sidste godt halvtreds år er fremkommet en stærkt krigerisk jihadisme, er

6. For Martin Krasniks svar til Jakob Skovgaard-Petersen og Jakob Skovgaard-Petersens modsvar, se Udenrigs 2:16-27, 2017 (udenrigs.dk/ wp-content/uploads/2017/12/ Udenrigs_2_2017_web.pdf, sidst tilgået 09.07.2018). "ufredens religion" en overmåde fjendtlig karakteristik af islam og muslimer, som er historisk overfladisk, både hvad angår fortiden og førnutiden, og sociologisk selektiv, når det kommer til nutiden. Krasnik selv har forsøgt at forsvare sin formulering. ${ }^{6}$ Jeg vil overlade det til læseren at bedømme, om han er sluppet synderligt godt fra det. 
Anbefalet læsning af Thomas Hoffmann
Friedmann, Yohanan. 2017. "Dar al-Islam and dar al-harb in Modern Indian Muslim Thought." In Giovanna Calasso \& Guiliano Lancioni (ed.): Dar al-Islam/Dar al-harb. Territories, People, Identities, 341-80. Leiden: Brill.

Kepel, Gilles. 200o. Jihad.

Expansion et déclin de l'islamisme. Paris: Gallimard.

Peters, Rudolph. 2004. Jihad $i$

klassisk og moderne islam.

København: Forlaget

Vandkunsten.

Roy, Olivier. 2004. Den

globaliserede islam. København:

Forlaget Vandkunsten.

Schwedler, Jillian. 2012. "Can

Islamists Become Moderates?

Rethinking the Inclusion-

Moderation Hypothesis", World

Politics 63(2).

Skovgaard-Petersen, Jakob. 2010.

Cook, Michael. 2014. Ancient Religions, Modern Politics: The Islamic Case in Comparative Perspective. Princeton: Princeton University Press.

Hamid, Shadi. 2016. Islamic exceptionalism: how the struggle over Islam is reshaping the Middle East. New York: St. Martin's Press. Hoffmann, Thomas. 2007. "Agonistic Poetics in the The Qur'ān: Self-referentialities, Refutations, and the Development of a Qur'ānic Self." In Stefan Wild (ed.): Self-referentiality in the Qur' ān, 39-57. Wiesbaden: Harrassowitz Verlag.

Inglehart, Ronald; Pippa Norris. 2003. "The True Clash of Civlizations." Foreign Policy 135: 62-70.

Koopmans, Ruud. 2014. Religious Fundamentalism and Out-Group Hostility among Muslims and
"Islam og vulgær-weberianismen." Kritik 197: 21-28. academia. edu/11496264/Islam_og_ vulg\%C3\%A6r-weberianismen. Skovgaard-Petersen, Jakob. 2016. Moderne islam. København: Gyldendal. Bogen rummer en samling af oversatte kilder, bl.a. af Rashid Rida, Muhammad Hussein Haykal, Mahmud Shaltut, Hassan al-Banna og Sayyed Qutb.

Skovgaard-Petersen, Jakob og Lasse Lavrsen. 2016. "Islamismen:

Bolværk, bremse eller katalysator?" Anmeldelse af Shadi Hameds bog i Føljeton. foljeton. $\mathrm{dk} / 17187 /$ islamismen-bolvaerkbremse-eller-katalysator-forarabisk-demokrati Smith, Wilfred Cantwell. 1981. On Understanding Islam. Haag: Mouton.

Christians in Western Europe. WZB Discussion Paper SP VI 2014-101. Berlin:

Wissenschaftszentrum Berlin für Sozialforschung.

More, Robert I. 2009. The formation of a persecuting society: authority and deviance in Western Europe, 950-1250. Malden, Mass.: Blackwell Publishing.

Pedersen, Johannes. 1958-6o. Israel. Branner og Korch.

Schwedler, Jillian. 2012. "Can Islamists Become Moderates? Rethinking the InclusionModeration Hypothesis", World Politics 63:2.

Smith, Jane I. 1975. An historical and semantic study of the term "Isläm" as seen in a sequence of Qur'ān commentaries. Missoula, Mont.: Scholars Press for Harvard Theological Review. 